\title{
H2AB2 wt Allele
}

National Cancer Institute

\section{Source}

National Cancer Institute. H2AB2 wt Allele. NCI Thesaurus. Code C154653.

Human H2AB2 wild-type allele is located in the vicinity of Xq28 and is approximately $1 \mathrm{~kb}$ in length. This allele, which encodes histone H2A-Bbd type 2/3 protein, plays a role in the modulation of both gene transcription and mRNA processing. 